\title{
Chromosomal similarities between Nephilidae and Tetragnathidae indicate unique evolutionary traits among Araneoidea
}

\author{
D. Araujo, E. Paula-Neto, A. D. Brescovit, D. M. Cella \& M. C. Schneider
}

To cite this article: D. Araujo, E. Paula-Neto, A. D. Brescovit, D. M. Cella \& M. C. Schneider (2015) Chromosomal similarities between Nephilidae and Tetragnathidae indicate unique evolutionary traits among Araneoidea, Italian Journal of Zoology, 82:4, 513-520, DOI:

10.1080/11250003.2015.1078418

To link to this article: https://doi.org/10.1080/11250003.2015.1078418
2
(c) 2015 Unione Zoologica Italiana

曲 Published online: 18 Aug 2015.

Submit your article to this journal $\pi$

Џll Article views: 406

View Crossmark data ¿

Citing articles: 1 View citing articles 5 


\title{
Chromosomal similarities between Nephilidae and Tetragnathidae indicate unique evolutionary traits among Araneoidea
}

\author{
D. ARAUJO ${ }^{1 \star}$, E. PAULA-NETO ${ }^{2}$, A. D. BRESCOVIT ${ }^{3}$, D. M. CELLA $^{4}, \&$ M. C. SCHNEIDER ${ }^{5}$ \\ ${ }^{1}$ Universidade Federal de Mato Grosso do Sul, UFMS, Setor de Biologia Geral, Centro de Ciências Biológicas e da Saúde, \\ Cidade Universitária, Bairro Universitário, Campo Grande, Brazil, ${ }^{2}$ Departamento de Biologia, Universidade Estadual \\ Paulista, UNESP, Instituto de Biociências, Rio Claro, Brazil, ${ }^{3}$ Instituto Butantan, Laboratório Especial de Coleções \\ Zoológicas, São Paulo, Brazil, ${ }^{4}$ In memoriam, and ${ }^{5}$ Universidade Federal de São Paulo, UNIFESP, Departamento de \\ Ciências Biológicas, Diadema, Brazil
}

(Received 3 September 2014; accepted 21 fuly 2015)

\begin{abstract}
Nephilid systematics has been subject to several changes in the last years, and the use of non-classical characters could be useful for evolutionary considerations. In this study, we analyzed the mitotic chromosomes of two nephilid spiders, Nephila clavipes and Nephila sexpunctata, using standard staining, silver nitrate impregnation and C-banding techniques, aiming to discuss the chromosomal similarities of Nephilidae and Tetragnathidae, and chromosome evolution within Nephila and Nephilingis. The basic karyotype characteristics observed in these two species $\left(2 \mathrm{n} \hat{\sigma}=22+\mathrm{X}_{1} \mathrm{X}_{2} 0\right.$ and monoarmed chromosomes) were similar to those registered for most araneoid families, i.e., Araneidae, Linyphiidae, Nephilidae, Nesticidae and Tetragnathidae. However, the occurrence of both prominent secondary constrictions and nucleolar organizer regions (NORs) is a shared characteristic between Nephilidae and Tetragnathidae, considering that these regions were not observed in any other Araneoidea species cytogenetically examined. Furthermore, in the present study we showed that within Nephila and Nephilingis species, change in the number and location of NORs as well as in the quantity and distribution of constitutive heterochromatin were the main events responsible for chromosome evolution, and that these differences can be useful in the cytotaxonomy of this group.
\end{abstract}

Keywords: Chromosomes, nucleolar organizer region, secondary constriction, Orbiculariae, karyotype evolution

\section{Introduction}

Nephilids are araneoid spiders whose composition, taxonomical ranking, internal and external relationships, and genera monophyly have been intensively discussed in the last years (Wunderlich 2004; Kuntner 2006; Kuntner et al. 2008, 2013; ÁlvarezPadilla et al. 2009; Dimitrov \& Hormiga 2009; Dimitrov et al. 2009; Hormiga \& Griswold 2014).

Several hypotheses have considered nephilids as part of Tetragnathidae and composed of (Phonognatha (Clitaetra (Nephila (Herennia + Nephilengys)))) (Hormiga et al. 1995; Griswold et al. 1998; Álvarez-Padilla 2007; Dimitrov \& Hormiga 2009). According to Wunderlich (2004), nephilids are a sister group to Araneidae. Kuntner (2006) proposed a new taxonomical ranking for the nephilids, raising them to familial status Nephilidae - constituted of (Clitaetra (Herennia (Nephilengys + Nephila))). Álvarez-Padilla et al. (2009) and Dimitrov et al. (2009) corroborated the monophyly of Nephilidae and their placement outside Tetragnathidae, as sister group to Araneidae, with an internal topology similar to that proposed by Hormiga et al. (1995), Griswold et al. (1998), Álvarez-Padilla (2007) and Dimitrov and Hormiga (2009), with the exclusion of Phonognatha. A recent phylogenomic analysis, aiming to discuss the orbweavers monophyly (Bond et al. 2014), shows a cladogram with Nephilidae closer to Araneidae than to Tetragnathidae. However, except for a brief mention on the position of Theridiidae, the internal Araneoidea phylogeny is not discussed, because,

*Correspondence: D. Araujo, Universidade Federal de Mato Grosso do Sul, UFMS, Setor de Biologia Geral, Centro de Ciências Biológicas e da Saúde, Cidade Universitária, Bairro Universitário, 79070-900, Campo Grande, Mato Grosso do Sul, Brazil. Tel/Fax: +55 67 33457311. Email: d.araujo@ufms.br

(C) 2015 Unione Zoologica Italiana 
according to these authors, denser taxon sampling is needed for a number of these clades.

Kuntner et al. (2013) confirmed Nephilidae as a monophyletic group and refused its placement as a Tetragnathidae subfamily, considering that the clade seems to be more closely related to "araneids" than to tetragnathids. Moreover, Kuntner et al. (2013) rejected the monophyly of Nephilengys, transferring some species to a new genus, Nephilingis. The monophyly of Nephila was also strongly questioned, but in this case, the author chose not to formally reclassify those species, which may not belong to this genus. Thus, Kuntner et al. (2013) denominated those species as the "Nephila" clade and proposed two alternative topologies: ((Nephilengys + Herennia) (Nephila ("Nephila" (Clitaetra + Nephilingis)))) or ((Nephilengys + Herennia) (Nephila (Nephilingis (Clitaetra + “Nephila”)))).

The World Spider Catalog (2015) lists 61 species of Nephilidae, now included in five genera: Clitaetra (six species from Africa/Asia), Herennia (11 Australasian species), Nephila (38 species with a worldwide distribution), Nephilengys (two Australasian species) and Nephilingis (four Afrotropical/South American species).

Cytogenetically, only Nephila clavata L. Koch, 1878, from Japan/India, and Nephilingis cruentata (Fabricius, 1775), under Nephilengys cruentata (Fabricius, 1775), from Brazil, were analyzed, both presenting $2 \mathrm{n} \hat{\sigma}=24$ and/or $2 \mathrm{n}+=26$, with the $\mathrm{X}_{1} \mathrm{X}_{2} \mathrm{O} / \mathrm{X}_{1} \mathrm{X}_{1} \mathrm{X}_{2} \mathrm{X}_{2}$ sex chromosome system, and telo-acrocentric chromosomes (Suzuki 1950, 1951; Datta \& Chatterjee 1988; Araujo et al. 2005). It is worthy to note that Nephila clavata as well as the South American Nephila clavipes (Linnaeus, 1767) and Nephila sexpunctata (Giebel, 1867) might be formally reclassified soon, and are provisionally treated as part of the "Nephila" clade by Kuntner et al. (2013).

The aim of this paper is to chromosomally characterize the two other nephilid species that occur in Brazil, both belonging to the genus Nephila: N. clavipes and $N$. sexpunctata, to determine the diploid number, type of sex chromosome system, chromosomal morphology, distribution of C-banding and nucleolar organizer regions (NORs), in order to discuss the nephilid chromosomal evolution.

\section{Material and methods}

The sample studied in this work included: 28 specimens of $N$. clavipes (10 adult females and 18 embryos -13 males and five females) from Rio Claro $\left(22^{\circ} 24^{\prime} 39^{\prime \prime} \mathrm{S}\right.$, $47^{\circ} 33^{\prime} 39^{\prime \prime}$ W), state of São Paulo, Brazil, and 14 individuals of $N$. sexpunctata (six adult females and eight embryos - three males and five females) from Tupã $\left(21^{\circ} 56^{\prime} 06^{\prime}\right.$ S, 50 $\left.50^{\circ} 50^{\prime \prime} \mathrm{W}\right)$, state of São Paulo, Brazil. Many attempts were made to obtain chromosomal preparations of male adult specimens, but the lack of mitotic and meiotic cells indicated that the spermatogenesis occurs in an early developmental stage in these species, as suggested by Araujo et al. (2005) for $N$. cruentata. The vouchers were deposited in the Laboratório Especial de Coleções Zoológicas, Instituto Butantan (IBSP), city of São Paulo, state of São Paulo (SP), Brazil (curator A.D. Brescovit). The chromosomal preparations were obtained from ovaries of adult females and from embryos, following the procedure described by Araujo et al. (2008): gonads were dissected in physiologic solution for insects (7.5 g Sodium Chloride $(\mathrm{NaCl}), 2.38 \mathrm{~g}$ Sodium phosphate dibasic $\left(\mathrm{Na}_{2} \mathrm{HPO}_{4}\right), 2.72 \mathrm{~g}$ Potassium dihydrogen phosphate $\left(\mathrm{KH}_{2} \mathrm{PO}_{4}\right)$, in $1 \mathrm{~L}$ of distilled water), transferred to colchicine solution $(0.16 \%$ in physiologic solution for insects) and left for $2 \mathrm{~h}$. A volume of hypotonic solution (tap water) equal to that of the colchicine solution was added. After 15 min of hypotonization, the material was placed in methanol:acetic acid (3:1) for $60 \mathrm{~min}$. Pieces of tissue were dissociated in a drop of $60 \%$ acetic acid on the surface of microscope slides. The preparation was dried on a metal heating plate $\left(35-40^{\circ} \mathrm{C}\right)$ and stained with 3\% Giemsa solution.

To establish the constitutive heterochromatin and nucleolar organizer region (NOR) distribution pattern, the chromosomes were submitted to C-banding (Sumner 1972) and silver nitrate impregnation (Howell \& Black 1980), respectively. The images of the chromosomes were captured using an Olympus BX51 microscope coupled to an Olympus DP71 digital camera with the DP Controller software. The chromosomes were morphologically classified following Levan et al. (1964).

\section{Results}

Mitotic metaphase cells of $N$. clavipes and $N$. sexpunctata showed $2 \mathrm{n}=26$ in female adult individuals and female embryos, and $2 \mathrm{n}=24$ in male embryos (Figure 1). The chromosomes presented telo-acrocentric morphology and gradually decreased in size. The sex chromosomes were not identified in Giemsa-stained cells due to the lack of differential characteristics in relation to the autosomes, such as size, condensation and pycnotic behavior. However, the diploid numbers observed in the sample of cells investigated, and the $\mathrm{C}$-banding pattern, revealed that the sex chromosomes of the $\mathrm{X}_{1} \mathrm{X}_{2} \mathrm{O} / \mathrm{X}_{1} \mathrm{X}_{1} \mathrm{X}_{2} \mathrm{X}_{2}$ system corresponded to the largest elements of the karyotype. Giemsa-stained cells showed secondary constriction in the terminal region of the $\mathrm{X}_{1}$ and $\mathrm{X}_{2}$ 


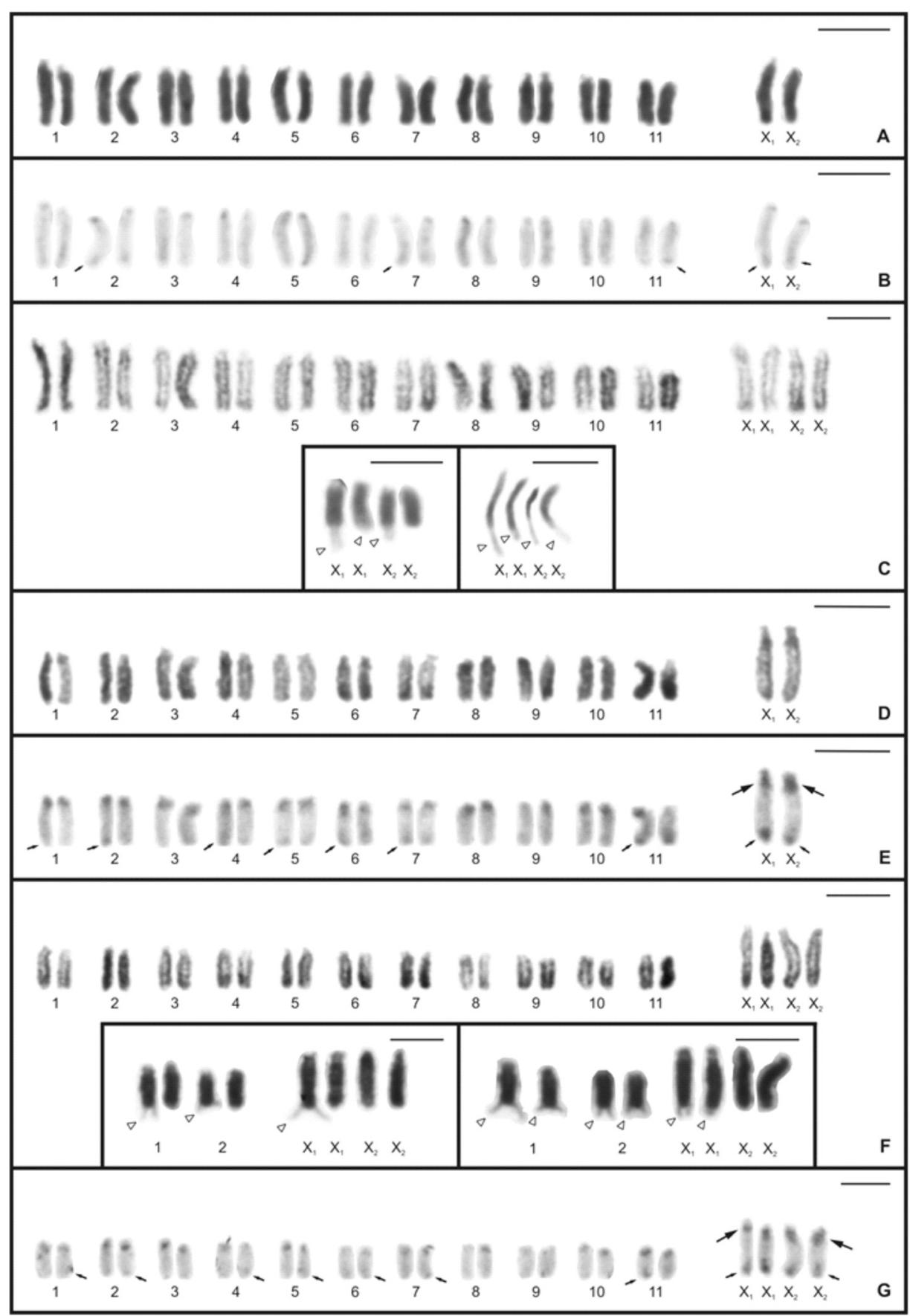

Figure 1. Karyotypes of Nephila clavipes (A-C) and Nephila sexpunctata (D-G) stained with Giemsa (A, C, D, F) and submitted to C-banding (B, E, G). A, B, D, E, male, with $2 \mathrm{n}=22+\mathrm{X}_{1} \mathrm{X}_{2} 0 . \mathbf{C}, \mathbf{F}, \mathbf{G}$, female, with $2 \mathrm{n}=22+\mathrm{X}_{1} \mathrm{X}_{1} \mathrm{X}_{2} \mathrm{X}_{2}$. The details in $\mathrm{c}$ and $\mathrm{f}$ show the heteromorphism in relation to the size of secondary constrictions. Arrowhead: secondary constriction. Large arrow: constitutive heterochromatin in paracentromeric region of long arm. Small arrow: constitutive heterochromatin in terminal region of long arm. Scale bar: $10 \mu \mathrm{m}$.

sex chromosomes of both species and pairs 1 and 2 of N. sexpunctata (Figure 1). An intraindividual heteromorphism in relation to the presence and/or size of these secondary constrictions were observed in both species.
C-banded metaphase cells showed constitutive heterochromatin in the pericentromeric region of all chromosomes (Figure 1B, E and G). In the $\mathrm{X}_{1}$ and $\mathrm{X}_{2}$ sex chromosomes of $N$. sexpunctata, the constitutive heterochromatin extended to the 
paracentromeric region of the long arm; in the $\mathrm{X}_{2}$ chromosome, this paracentromeric block was larger than in the $\mathrm{X}_{1}$ chromosome (Figure $1 \mathrm{E}$ and $\mathrm{G}$ ). Moreover, in both species, some chromosomes exhibited a telomeric C-band in the long arm, which were tenuous in autosomal pairs 2, 7 and 11 and sex chromosomes of $N$. clavipes (Figure 1B), and pairs 1, 2, 4, $5,6,7$ and 11 of $N$. sexpunctata (Figure $1 \mathrm{E}$ and $\mathrm{G}$ ). The telomeric C-bands in the sex chromosomes of both species and pairs 1 and 2 of $N$. sexpunctata were coincident with the secondary constriction.

The silver impregnation revealed six and eight NORs in male and female metaphase cells of $N$. clavipes, respectively, which were located on the long-arm terminal region of pairs 5, 6, $\mathrm{X}_{1}$ and $\mathrm{X}_{2}$ chromosomes (Figure $2 \mathrm{~A}-\mathrm{F}$ ); in N. sexpunctata, 14 and 16 NORs localized on autosomal pairs $1,2,3,5$, 6,11 and $\mathrm{X}_{1}$ and $\mathrm{X}_{2}$ sex chromosomes were observed in cells of males and females, respectively (Figure 2G-L). The NORs located on $\mathrm{X}_{1}$ and $\mathrm{X}_{2}$ sex chromosomes of $N$. clavipes seemed to be larger than those of $N$. sexpunctata (Figure 2D, F, H, J and L). The NORs on sex chromosomes of both species, and on the first and second autosomal pairs of $N$. sexpunctata, were coincident with the secondary constrictions and constitutive heterochromatin.

\section{Discussion}

Nephilidae chromosomes and araneoid karyotype evolution

The Nephila species studied here presented karyotype characteristics $\left(2 \mathrm{n} \hat{0}=22+\mathrm{X}_{1} \mathrm{X}_{2} 0\right.$ and monoarmed chromosomes) similar to those described for the other nephilids chromosomally analyzed up to now: Nephila clavata (Suzuki 1950, 1951; Datta \& Chatterjee 1988) and Nephilingis cruentata (under Nephilengys cruentata - Araujo et al. 2005). These chromosomal features seem to be conserved within Araneoidea, considering that they were also observed in all six araneoid spider families cytogenetically examined: Araneidae, Linyphiidae, Nephilidae, Nesticidae, Tetragnathidae and Theridiidae (Araujo et al. 2015). With the exception of Theridiidae, in which $2 \mathrm{n} \widehat{O}=20+\mathrm{X}_{1} \mathrm{X}_{2} 0$ predominates, the $2 n{ }^{\lambda}=22+X_{1} X_{2} 0$ occurs in most species of the other five araneoid families analyzed, along with less frequent karyotype formulae (for a review, see Araujo et al. 2015). It is true that the karyotype $2 \mathrm{n} \hat{0}=22+\mathrm{X}_{1} \mathrm{X}_{2} 0$, with monoarmed chromosomes, was also recorded in many other Entelegynae families. However, except in Cybaeidae, Mimetidae and Psechridae for which only one species has been karyotyped, there are no entelegyne families in which these chromosomal characteristics are the most frequent (Araujo et al. 2015). The chromosome numbers registered in Uloboridae, which together with Deinopidae forms Deinopoidea, the sister group to Araneoidea (Griswold et al. 1998), are markedly low $(2 \mathrm{n}=10,17,18,19$ and 22; Araujo et al. 2015).

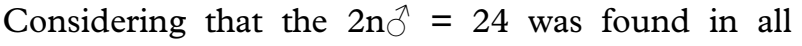
analyzed araneoids and was absent in Uloboridae, the karyotype $2 \mathrm{n} \hat{0}=22+\mathrm{X}_{1} \mathrm{X}_{2} \mathrm{O}$, with monoarmed chromosomes, could be hypothesized as ancestral for Araneoidea. However, it is worth pointing out that there is no cytogenetical data for seven araneoid families: Anapidae, Cyatholipidae, Mysmenidae, Pimoidae, Symphytognathidae, Synotaxidae and Theridiosomatidae (Araujo et al. 2015).

Taking into account that the ancestral karyotype proposed for entelegyne spiders is $2 \mathrm{n} \hat{0}=42, \mathrm{X}_{1} \mathrm{X}_{2} 0$, with monoarmed elements (Král et al. 2006), both araneoids and uloborids underwent chromosomal rearrangements that reduced their diploid numbers, but to different degrees, with the number becoming lowest in species of the family Uloboridae. Given that the chromosomal morphology, excluding some very few cases, is also monoarmed in araneoid spiders (Araujo et al. 2015), tandem fusions and/or centric fusions followed by pericentric inversions seem to be the rearrangements involved in these reductions of diploid number. Centric fusion is a well-documented mechanism that commonly underlies the karyotype evolution of spiders, as registered in some araneids with $2 \mathrm{n} \hat{0}=14$ (10 biarmed and four monoarmed chromosomes), a karyotype that

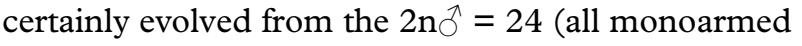
chromosomes) (Hackman 1948; Suzuki 1951; Amalin et al. 1993), and in one araneid specimen of Parawixia velutina (Taczanowski, 1873), which was heterozygous for a centric fusion, presenting an odd metacentric element in the karyotype (Araujo et al. 2011). Evidence of several pericentric inversions were encountered by Stávale et al. (2010) in Argyrodes elevatus Taczanowski, 1873 (Theridiidae), in which all 20 autosomal chromosomes are biarmed, contrasting with the majority of theridiid species, in which all 20 autosomes are monoarmed (Araujo et al. 2015).

\section{Chromosomal data and Nephilidae placement within araneoids}

Considering that the karyotype $2 \mathrm{n}=24, \mathrm{X}_{1} \mathrm{X}_{2} 0$, with monoarmed chromosomes, recorded in all nephilid species analyzed up to now (Suzuki 1950, 1951; Datta \& Chatterjee 1988; Araujo et al. 2005; present work), is similar to that predominantly found in tetragnathids and araneids 


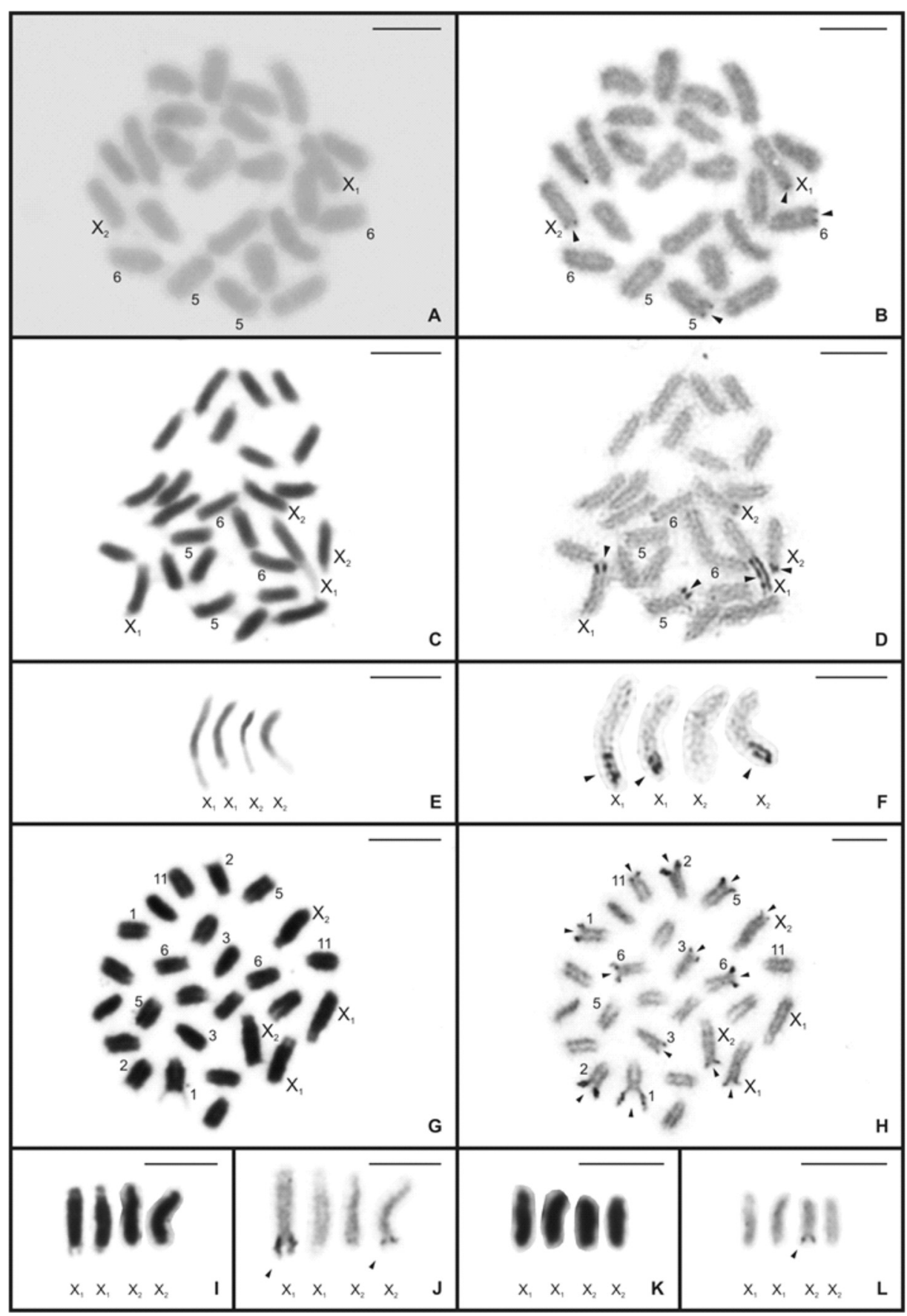

Figure 2. Mitotic chromosomes of Nephila clavipes $(\mathbf{A}-\mathbf{F})$ and Nephila sexpunctata $(\mathbf{G}-\mathbf{L})$ stained with Giemsa $(\mathrm{A}, \mathrm{C}, \mathrm{E}, \mathrm{G}, \mathrm{I}, \mathrm{K})$ and submitted to silver impregnation (B, D, F, H, J, L). A, B, male, with $2 \mathrm{n}=22+\mathrm{X}_{1} \mathrm{X}_{2} 0 . \mathbf{C}, \mathbf{D}, \mathbf{G}, \mathbf{H}$, female, with $2 \mathrm{n}=22+\mathrm{X}_{1} \mathrm{X}_{1} \mathrm{X}_{2} \mathrm{X}_{2}$. Arrowhead: nucleolar organizer regions. Scale bar: $10 \mu \mathrm{m}$.

(Araujo et al. 2015), the basic cytogenetic data available do not provide additional clues into the question of the position of nephilids within Araneoidea, whether they are more closely related to Tethagnathidae or Araneidae (Hormiga et al. 1995; Griswold et al. 1998; Wunderlich 2004; Kuntner 2006; Kuntner et al. 2008, 2013;
Álvarez-Padilla et al. 2009; Dimitrov \& Hormiga 2009; Dimitrov et al. 2009). Nevertheless, the presence of sex chromosomes with prominent secondary constrictions in both Nephila species studied here, and in Meta and Metellina species (Tetragnathidae) investigated by Král et al. (2011), is at least one shared character between 
Nephilidae and Tetragnathidae. Those regions were not described on sex chromosomes in any of the 14 species of Araneidae, Linyphiidae, Nesticidae and Theridiidae that were cytogenetically analyzed with similar procedures to that employed here (Matsumoto 1977; Tugmon et al. 1990; Gunnarsson \& Andersson 1992; Araujo et al. 2010, 2011; Stávale et al. 2010; Zhao et al. 2010). The importance of sharing secondary constrictions on sex chromosomes is still more relevant when we notice that these regions are also related to NORs, as revealed by silver impregnation in the species analyzed here and in the tetragnathid spiders examined by Král et al. (2011). The proposition of an $\mathrm{X}$-linked NOR as a synapomorphy to Nephilidae + Tetragnathidae was pointed out by Král et al. (2011), considering that this NOR pattern was not observed in any entelegyne spiders. The absence of secondary constrictions in Nephila clavata can be due to the fact that Suzuki (1950) presented the karyotype data only in a short table, without detailed descriptions of chromosome features. Suzuki (1951) analyzed only male meiotic divisions that are not adequate to see these regions. Moreover, in Suzuki (1951) and Datta and Chatterjee (1988), the methods did not include all steps used in the present work, which are ideal for visualizing chromosomal regions such as secondary constrictions.

\section{NOR and constitutive heterochromatin evolution in nephilids}

In spiders, NORs are usually located on autosomes (Araujo et al. 2012). This condition can be considered basal for the clade composed of ("Nephila" (Nephilingis + Clitaetra)). In Nephilingis, conspicuous NORs remained exclusively on pairs 1,2 and 3 of $N$. cruentata, as revealed by Araujo et al. (2005). If one assumes that these are autosomal pairs, in the "Nephila" species studied here, the rDNA cistrons probably underwent translocation from autosomes to sex chromosomes, taking into account that both types of chromosomes possess NORs. This autosome-sex chromosome rDNA translocation is even more remarkable in N. clavipes ("Nephila" African clade, Kuntner et al. 2013), due to two features: (1) $N$. clavipes possess a lower number of autosomes carrying NORs (two pairs) than the basal N. sexpunctata (six pairs) ("Nephila" Australasian clade, Kuntner et al. 2013); (2) in N. clavipes, the NORs on $\mathrm{X}_{1}$ and $\mathrm{X}_{2}$ chromosomes are larger than those observed on sex chromosomes of the basal N. sexpunctata.
However, we cannot exclude the possibility that the pairs 1 and 2 of $N$. cruentata analyzed by Araujo et al. (2005) are, in fact, the sex chromosomes, because in that work, the authors did not identify the sex chromosomes The eventual confirmation of NORs on sex chromosomes of $N$. cruentata would be an additional chromosome similarity between Nephilidae and Tetragnathidae. Association of NORs with constitutive heterochromatin, as encountered in both "Nephila" species (present work) and Nephilingis (under Nephilengys, Araujo et al. 2005), reinforces the proposition that translocations were involved in the change of NORs from autosomes to sex chromosomes (Cerbah et al. 1998; Lohe \& Roberts 2000). Interestingly, a high rate of rDNA cistron translocation between autosomes and sex chromosomes, as verified here and by Král et al. (2011), was accompanied by a high evolution rate in the ribosomal genes (18S and 28S) in nephilids, when compared with the outgroups, as stated by Kuntner et al. (2013).

The pericentromeric C-banding pattern verified in the chromosomes of $N$. clavipes and $N$. sexpunctata is similar to that described for the majority of Entelegynae spiders analyzed regarding this aspect (Brum-Zorrilla \& Cazenave 1974; Brum-Zorrilla \& Postiglioni 1980; Rowell 1985; Datta \& Chatterjee 1988; Gorlova et al. 1997; Rodríguez-Gil et al. 2007), including the nephilid $N$. clavata (Datta \& Chatterjee 1988) and the tetragnathid Metellina merianae (Scopoli, 1763) (Král et al. 2011). Nevertheless, this pattern differs from that recorded by Araujo et al. (2005) in N. cruentata, in which the C-bands were absent from the pericentromeric region of most chromosomes, and occurred predominantly in interstitial and/or telomeric regions of some chromosomes. This notable difference in the C-banding pattern between Nephila and Nephilingis indicated that change in the quantity and distribution of constitutive heterochromatin is also involved in chromosome evolution of these related species with similar karyotype features.

\section{Acknowledgements}

This research was supported through funding from the Fundação de Amparo à Pesquisa do Estado de São Paulo, FAPESP (2011/21643-1) and Conselho Nacional de Desenvolvimento Científico e Tecnológico - CNPq (ADB, \# 300169/1996-5). We are indebted to two anonymous reviewers for critical reading and valuable suggestions for the improvement of the manuscript, and Taylor \& Francis staff for language improvement. 


\section{References}

Álvarez-Padilla F. 2007. Systematics of the spider genus Metabus O. P.-Cambridge, 1899 (Araneoidea: Tetragnathidae) with additions to the tetragnathid fauna of Chile and comments on the phylogeny of Tetragnathidae. Zoological Journal of the Linnean Society 150:285-335. doi:10.1111/j.1096-3642.2007.00304.x.

Álvarez-Padilla F, Dimitrov D, Giribet G, Hormiga G. 2009. Phylogenetic relationships of the spider family Tetragnathidae (Araneae, Araneoidea) based on morphological and DNA sequence data. Cladistics 25:109-146. doi:10.1111/ cla.2009.25.issue-2.

Amalin DM, Barrion AA, Jayoma M. 1993. Comparative karyomorphology of two Neoscona species (Araneae: Araneidae). Philippine Entomologist 9:1-6.

Araujo D, Cella DM, Brescovit AD. 2005. Cytogenetic analysis of the Neotropical spider Nephilengys cruentata (Araneomorphae, Tetragnathidae): Standard staining, NORs, C-Band and basespecific fluorochromes. Brazilian Journal of Biology 65:193202. doi:10.1590/S1519-69842005000200002.

Araujo D, Maia UM, Brescovit AD. 2010. The first cytogenetic characterization of the poisonous black widow spider Latrodectus gr. curacaviensis from Brazil, with chromosomal review of the family Theridiidae (Arachnida, Araneae). Micron 41:165-168. doi:10.1016/j.micron.2009.10.002.

Araujo D, Mattos VF, Giroti AM, Kraeski MG, Carvalho LS, Brescovit AD. 2011. Cytogenetical characterization of six orb-weaver species and review of cytogenetical data for Araneidae. Journal of Arachnology 39:337-344. doi:10.1636/ CB10-88.1.

Araujo D, Rheims CA, Brescovit AD, Cella DM. 2008. Extreme degree of chromosome number variability in species of the spider genus Scytodes (Araneae, Haplogynae, Scytodidae). Journal of Zoological Systematics and Evolutionary Research 46:89-95. doi:10.1111/j.1439-0469.2007.00457.x.

Araujo D, Schneider MC, Paula-Neto E, Cella DM. 2012. Sex chromosomes and meiosis in spiders: A review. In Meiosis Molecular mechanisms and cytogenetic diversity: Swan A, editor. Rijeka: InTech. pp. 87-108.

Araujo D, Schneider MC, Paula-Neto E, Cella DM. 2015. The spider cytogenetic database version 3.5. Available: www.arthro podacytogenetics.bio.br/spiderdatabase. Accessed Mar 201523.

Bond JE, Garrison NL, Hamilton CA, Godwin RL, Hedin M, Agnarsson I. 2014. Phylogenomics resolves a spider backbone phylogeny and rejects a prevailing paradigm for orb web evolution. Current Biology 24:1765-1771. doi:10.1016/j.cub.2014.06.034.

Brum-Zorrilla N, Cazenave AM. 1974. Heterochromatin localization in the chromosomes of Lycosa malitiosa (Arachnida). Experientia 30:94-95. doi:10.1007/BF01921621.

Brum-Zorrilla N, Postiglioni A. 1980. Karyological studies on Uruguayan spiders I. Banding pattern in chromosomes of Lycosa species (Araneae-Lycosidae). Genetica 54:149-153. doi:10.1007/BF00055984.

Cerbah MA, Coulaud J, Siljak-Yakovlev S. 1998. rDNA organization and evolutionary relationships in the genus Hypochaeris (Asteraceae). Journal of Heredity 89:312-318. doi:10.1093/ jhered/89.4.312.

Datta SN, Chatterjee K. 1988. Chromosomes and sex determination in 13 araneid spiders of North-Eastern India. Genetica 76:91-99. doi:10.1007/BF00058807.

Dimitrov D, Benjamin SP, Hormiga G. 2009. A revised phylogenetic analysis for the spider genus Clitaetra Simon, 1889 (Araneae, Araneoidea, Nephilidae) with the first description of the male of the Sri Lankan species Clitaetra thisbe. Bulletin of the Museum of
Comparative Zoology 159:301-323. doi:10.3099/0027-4100159.6.301.

Dimitrov D, Hormiga G. 2009. Revision and cladistic analysis of the orbweaving spider genus Cyrtognatha Keyserling, 1881 (Araneae, Tetragnathidae). Bulletin of the American Museum of Natural History 317:1-140. doi:10.1206/317.1.

Gorlova OYU, Gorlov IP, Nevo E, Logunov DV. 1997. Cytogenetic studies on seventeen spider species from Israel. Bulletin of the British Arachnological Society 10:249-252.

Griswold CE, Coddington JA, Hormiga G, Scharff N. 1998. Phylogeny of the orb-web building spiders (Araneae, Orbiculariae: Deinopoidea, Araneoidea). Zoological Journal of the Linnean Society 123:1-99. doi:10.1111/zoj.1998.123. issue- 1 .

Gunnarsson B, Andersson A. 1992. Chromosome variation in embryos of a solitary spider, Pityohyphantes phrygianus, with skewed sex ratio. Hereditas 117:85-91. doi:10.1111/j.16015223.1992.tb00011.x.

Hackman W. 1948. Chromosomenstudien an Araneen mit besonderer berücksichtigung der geschlechtschromosomen. Acta Zoologica Fennica 54:1-101.

Hormiga G, Eberhard WG, Coddington JA. 1995. Web construction behavior in Australian Phonognatha and the phylogeny of nephiline and tetragnathid spiders (Araneae, Tetragnathidae). Australian Journal of Zoology 43:313-364. doi:10.1071/ZO9950313.

Hormiga G, Griswold CE. 2014. Systematics, phylogeny, and evolution of orb-weaving spiders. Annual Review of Entomology 59:487-512. doi:10.1146/annurev-ento-011613-162046.

Howell WM, Black DA. 1980. Controlled silver staining of nucleolus organizer regions with protective colloidal developer: A 1-step method. Experientia 36:1014-1015. doi:10.1007/ BF01953855.

Král J, Kořínková T, Forman M, Krkavcová L. 2011. Insights into the meiotic behavior and evolution of multiple sex chromosome systems in spiders. Cytogenetic Genome Research 133:43-66. doi:10.1159/000323497.

Král J, Musilová J, St'áhlavsky F, Rezác M, Akan Z, Edwards RL, Coyle FA, Almerje CR. 2006. Evolution of the karyotype and sex chromosome systems in basal clades of araneomorph spiders (Araneae, Araneomorphae). Chromosome Research 14:859-880. doi:10.1007/s10577-006-1095-9.

Kuntner M. 2006. Phylogenetic systematics of the Gondwanan nephilid spider lineage Clitaetrinae (Araneae, Nephilidae). Zoologica Scripta 35:19-62. doi:10.1111/zsc.2006.35.issue-1.

Kuntner M, Arnedo MA, Trontelj P, Lokovšek T, Agnarsson I. 2013. A molecular phylogeny of nephilid spiders: Evolutionary history of a model lineage. Molecular Phylogenetics and Evolution 69:961-979. doi:10.1016/j.ympev.2013.06.008.

Kuntner M, Coddington JA, Hormiga G. 2008. Phylogeny of extant nephilid orb-weaving spiders (Araneae, Nephilidae): Testing morphological and ethological homologies. Cladistics 24:147-217. doi:10.1111/j.1096-0031.2007.00176.x.

Levan A, Fredga K, Sandberg AA. 1964. Nomenclature for centromeric position on chromosomes. Hereditas 52:201-220. doi:10.1111/j.1601-5223.1964.tb01953.x.

Lohe AR, Roberts PA. 2000. Evolution of DNA in heterochromatin: The Drosophila melanogaster sibling species subgroup as a resource. Genetica 109:125-130. doi:10.1023/A:1026588217432.

Matsumoto S. 1977. An observation of somatic chromosomes from spider embryo-cells. Acta Arachnologica 27:167-172. doi:10.2476/asjaa.27.Specialnumber_167.

Rodríguez-Gil SG, Merani MS, Scioscia CL, Mola LM. 2007. Cytogenetics in three species of Polybetes Simon 1897 from Argentina (Araneae, Sparassidae). I. Karyotype and 
chromosome banding pattern. Journal Arachnology 35:227237. doi:10.1636/S05-69.1.

Rowell DM. 1985. Complex sex-linked fusion heterozygosity in the Australian huntsman spider Delena cancerides (Araneae: Sparassidae). Chromosoma 93:169-176. doi:10.1007/ BF00293165.

Stávale LM, Schneider MC, Araujo D, Brescovit AD, Cella DM. 2010. Chromosomes of Theridiidae spiders (Entelegynae): Interspecific karyotype diversity in Argyrodes and diploid number intraspecific variability in Nesticodes rufipes. Genetics and Molecular Biology 33:663-668. doi:10.1590/S141547572010005000076.

Sumner AT. 1972. A simple technique for demonstrating centromeric heterochromatin. Experimental Cell Research 75:304306. doi:10.1016/0014-4827(72)90558-7.

Suzuki S. 1950. Sex determination and karyotypes in spiders. Zoological Magazine 59:31-32.
Suzuki S. 1951. Cytological studies in spiders. I. A comparative study of the chromosomes in the family Argiopidae. Journal of science of the Hiroshima University, Series B, Division 112:67-98.

Tugmon CR, Brown JD, Horner NV. 1990. Karyotypes of seventeen USA spiders species (Araneae, Araneidae, Gnaphosidae, Loxoscelidae, Lycosidae, Oxyopidae, Philodromidae, Salticidae and Theridiidae). The Journal of Arachnology 18:41-48.

World Spider Catalog. 2015. World Spider Catalog. Natural History Museum Bern. Available: http://wsc.nmbe.ch. Accessed Mar 201523.

Wunderlich J. 2004. Fossil spiders in Amber and Copal. Beitrage Zur Araneologie 3:1908.

Zhao Y, Ayoub NA, Hayashi CY. 2010. Chromosome mapping of dragline silk genes in the genomes of widow spiders (Araneae, Theridiidae). PLoS ONE 5:e12804. doi:10.1371/journal. pone. 0012804 . 